\title{
The public costs of climate-induced financial instability
}

Francesco Lamperti ${ }^{\mathrm{a}, \mathrm{d}, \mathrm{k}}$, Valentina Bosetti ${ }^{\mathrm{b}, \mathrm{d}}$, Andrea Roventini ${ }^{\mathrm{a}, \mathrm{e}}$, Massimo Tavoni ${ }^{\mathrm{c}, \mathrm{d}}$

${ }^{a}$ Institute of Economics and EMbeDS, Scuola Superiore Sant'Anna

${ }^{\mathrm{b}}$ Department of Economics, Bocconi University

${ }^{c}$ School of Management, Politecnico di Milano

d RFF-CMCC European Institute on Economics and the Environment (EIEE)

e Observatoire Francais des Conjonctures Economiques

*Corresponding author - emails: francesco.lamperti@eiee.org; f.lamperti@santannapisa.it. 
Recent evidence suggests that climate change will significantly affect economic growth and several productive elements of modern economies, such as workers and land $(18 ; 11 ; 14)$. Although historical records indicate that economic shocks might lead to financial instability, few studies focused on the impact of climate change on the financial actors (19; 17). This paper examines how climate-related damages impact on the stability of the global banking system. We use an agent-based climatemacroeconomic model calibrated on stylized facts, future scenarios and climate impact functions (35) affecting labour and capital. Our results indicate that climate change will increase the frequency of banking crises (+26-148\%). Rescuing insolvent banks will cause an additional fiscal burden of approximately $5 \%$ to $15 \%$ of GDP per year and an increase of public debt to GDP by a factor of 2 . We estimate that around $20 \%$ of such effects are caused by the deterioration of banks' balance sheets induced by climate change. Macro-prudential regulation attenuates bailout costs, but only moderately. Our results show that leaving out the financial system from climateeconomy integrated assessment may lead to an underestimation of climate impacts, and that financial regulation can play a role in mitigating them.

Historical records suggest that financial crises are not rare events (see Supplementary Figure 1). On a global scale, the past 50 years have witnessed myriad of crises, entailing an average cost of around 35\% of the GDP of the country facing the event in terms of output lost and a fiscal burden for the government of $13 \%$ of the country's GDP (29). Such crises reflect imperfections in the functioning of modern economies, financial systems and, in particular, capital allocation mechanisms.

Recent research on climate damages emphasize that increased temperatures will have significant, non-linear effects on the global economy $(43,25,11 ; 14,24,20,32)$. Physical impacts from unmitigated climate change could also threaten the financial system. For example, increasing stocks of capital at risk (due to floods, landslides or storm surges) would adversely affect insurance companies, thus raising premiums. The deterioration of the balance sheets of affected firms and consumers might induce losses in the lender banks. Specifically, the inability to repay obligations - because of insolvency - generates what are usually referred to as non-performing loans (or bad debt) in the balance sheet of banks and other financial institutions, with possible systemic implications such as those experienced on a global scale during the 2008 financial crisis. Taxpayers are the final groups bearing the risks of instability. Thus, financial crises entail costs both to the economy, because of contractions in demand and production, and to public finances (fiscal costs), due to the rescuing interventions of the governments.

The literature on climate change impacts and finance is scant but rapidly developing. In a 2015 speech, the governor of the Bank of England distinguished between climate-related physical and liability and transition risks (15). Some recent studies highlight the exposure of the global financial system to such risks $(19 ; 4,7,42 ;, 17,47,33)$, though none examine the public costs of the ensuing instability and the role of the latter in amplifying the impact of climate on growth. These preliminary studies have prompted increased attention to how central banks and financial regulation authorities can manage climate-related risks to financial stability (13; 23).

This paper contributes to the debate by analyzing the impact of climate change on the global banking system, quantifying banking crises and the public costs of bailing out insolvent banks. We single out the potential underestimation of climate change damage estimates that neglect this element. We use a recently developed global agent-based integrated assessment model $(30,31)$ to simulate the behaviour of an economic system comprising heteroge- 
neous households, firms, energy plants, banks and policy makers (a government and central bank) exposed to climate damages affecting the productivity of labour and the stock of capital owned by firms. The model, which we calibrate on stylized facts, reproduces economic growth and emissions consistent with the Shared Socio-economic Pathways (SSP5 as central case; see 39. Supplementary Methods, Section D and Supplementary Results, Section A for SSP1). We consider four scenarios of climate damages: a baseline, with no climate change, and three scenarios in which global warming affects the productivity of labour, capital, or both, respectively. Empirical studies have found that warming significantly reduces both operational and cognitive tasks of workers, thus lowering labour productivity $(44 ; 45,46 ; 1 ;, 28)$. Likewise, evidence shows that climate change can affect the stock and quality of capital directly - through crowding out - and indirectly - through extreme events (5). As the magnitude of climate change impacts is extremely uncertain (40), we perform an extensive sensitivity analysis around our central value based on estimates from (35). Damages affect the profitability of firms, which might go bankrupt, creating non-performing loans (i.e. loans that will not be repaid) in the balance sheet of banks. To prevent instability of the financial system, when a bank's equity turns negative, we test a bailing-out policy such that the government immediately intervenes by providing fresh capital, saving the insolvent bank. The employed model, described in Methods, does not allow for analytical, closed-form solutions. This general feature of agent-based models has forced us to perform Monte Carlo analyses to remove the cross-simulation variability and to present results as averages over 500 model runs, as standard in the literature $(22 ; 3)$.

Table 1 summarizes the behaviour of main macroeconomic, financial and climate indicators across the three impact scenarios and the baseline. Climate change has significant negative effects on economic growth, reducing the annual pace from $3.5 \%$ in the baseline to 2.0-2.9\%, depending on the climate impact scenario. Qualitatively, we confirm these figures when we target an SSP1 scenario (Supplementary Results, Section A). Impacts on the macroeconomy are stronger when climate damages hit labour productivity, reflecting the prevalence of the labour share in most modern economies (36). Over and above this effect, the accumulation of losses in the banking sector sharpens the impacts, as detailed subsequently. Financial crises and banks' bailouts occur even in the absence of climate change: average fiscal costs in the baseline (10.3\% of GDP) are comparable to historic values (see Supplementary Figure 1). However, the three impact scenarios significantly raise the number of banks' rescues the government must engage in to preserve financial stability, with fiscal costs increasing by a factor ranging from 1.52 (95\% CI: 1.04; 2.00) to 2.43 (95\% CI: 1.86; 3.00) depending on the scenario. Such effects are driven by the stock of bad debt accumulating in the financial system as a consequence of cascades of firms' bankruptcies induced by climate damages.

The number of bailouts induced by climate impacts increase over time (Figure 1 panel a), with the largest increase taking place between 2030 and 2060, when temperature anomaly reaches approximately 3 Celsius degrees - consistent with an SSP5 scenario - and the corresponding average damage to firms exceeds $2 \%$. Under labour and capital damages, banks' bailouts increase faster than in all other scenarios, and at the end of the century, they become more than twice as frequent as in the baseline (average of 25.0 vs. 9.8 in the last decade of simulation), imposing costs to the government reaching $40 \%$ of GDP per episode (Figure 1, panel b). Such costs negatively affect the public budget and, over time, translate in an increasing stock of government debt (Figure 1. panel c). By the end of the century, the expected debt to GDP ratio is slightly above $400 \%$, which should be compared with the $85 \%$ of the scenario with no climate change. Note also that bailouts are less frequent in two climate impact scenarios 
Table 1: Main macroeconomic and climate indicators in the baseline and impact scenarios.

\begin{tabular}{lcccc}
\hline & $\begin{array}{c}\text { No } \\
\text { Climate Change }\end{array}$ & $\begin{array}{c}\text { Labour Productivity } \\
\text { Damages }\end{array}$ & $\begin{array}{c}\text { Capital Stock } \\
\text { Damages }\end{array}$ & $\begin{array}{c}\text { Labour and Capital } \\
\text { Damages }\end{array}$ \\
\hline GDP growth (\%) & 3.4 & 2.2 & 2.9 & 2.0 \\
& $(0.002)$ & $(0.004)$ & $(0.004)$ & $(0.003)$ \\
Firms' 10y Insolvency Likelihood (\%) & 15.2 & 32.4 & 38.8 & 47.1 \\
& $(0.031)$ & $(0.047)$ & $(0.050)$ & $(0.052)$ \\
Banks' Equity to Total Asset ratio (\%) & 12.0 & 7.5 & 9.6 & 5.3 \\
Public Bailouts/10y & $(0.025)$ & $(0.034)$ & $(0.029)$ & $(0.041)$ \\
Cost of Bailouts per year (\% GDP) & 9.1 & 14.2 & 11.5 & 22.6 \\
& $(1.28)$ & $(2.15)$ & $(3.02)$ & $(3.96)$ \\
Average debt over GDP ratio & 10.3 & 15.7 & 14.6 & 25.0 \\
& $(0.013)$ & $(0.027)$ & $(0.029)$ & $(0.031)$ \\
Temperature Anomaly 2100 & 0.83 & 1.55 & 1.38 & 1.77 \\
& $(0.04)$ & $(0.09)$ & $(0.07)$ & $(0.11)$ \\
Cumulative emissions at 2100 (GtCO2-eq) & $5.4^{\dagger}$ & 5.0 & 5.2 & 4.8 \\
& $(0.312)$ & $(0.461)$ & $(0.411)$ & $(0.470)$ \\
\end{tabular}

Note: All values refer to averages from a Monte Carlo exercise of size 500; standard deviations are in parenthesis. ${ }^{\dagger}$ indicates the temperature anomaly that would have realized in the presence of climate change for the stock of emissions summarized in the lines below.

than the baseline during the first couple of simulation decades (Figure 1 panel a). This suggests beneficial effects of mild climate change (14, 11, see Supplementary Results, Section A for evidence of a non-linear relationship between bailouts and GDP losses across scenarios). In an SSP1 future, the impacts are less severe but sizeable: firms' insolvency and bailouts' frequency increase by $+33 \%$ and $+9 \%$, respectively (vs. a baseline without warming), and public debt to GDP averages 250\% in the year 2100 (see Supplementary Results, Section A).

Crises in the banking system exacerbate the downturns in the real sector through credit crunches, that is periods of substantially reduced credit inflow blocking the investments of firms $(8,10)$. The combination of such events and the direct damages that climate change exerts on economic agents in our impact scenarios (see Methods) produce large detrimental effects on the long-term performance of the economy (Figure 2, panels a and b). While in the absence of climate change the yearly growth rates of output are almost identical over the century, when firms suffer labour and capital damages in an SSP5 world, the economy gradually shifts towards regimes of progressively weaker paces of developments and greater volatility, with average growth rates corresponding to $91 \%$ (95\% CI: 67\%; 119\%), 84\% (95\% CI: 65\%; 108\%), $68 \%$ (95\% CI: 34\%; 103\%) and 48\% (95\% CI: 33\%; 91\%) than those in the baseline for the first-, second-, third- and fourth-century quarters, respectively. In an SSP 1 future, we show that output growth rate contracts by $9 \%$ (with respect to a scenario without warming; see Supplementary Results, Section A). Damages to labour productivity cut firms' operative margins and depress wages and the aggregate demand, with dynamically adverse effects on technical change and the Schumpeterian engine of growth. Moreover, capital stock losses amplify fluctuations in the business cycle, exacerbating the reliance of firms on external financing (30). Finally, the ability of the banking sector to alleviate the direct implications of climate impacts on firms weakens from the cumulated effects of non-performing loans. See Supplementary Results, Section A for a comparison of the economic damages shown in the current study with previous findings.

To establish the contribution of climate-induced financial distress to such a shrinkage of economic performances, we run an additional simulation experiment comparing the actual bailout mechanism with an alternative regime. In the latter, the government absorbs any nonperforming loan, thus fully preserving banks' equity and lending capacity. Such experiment 


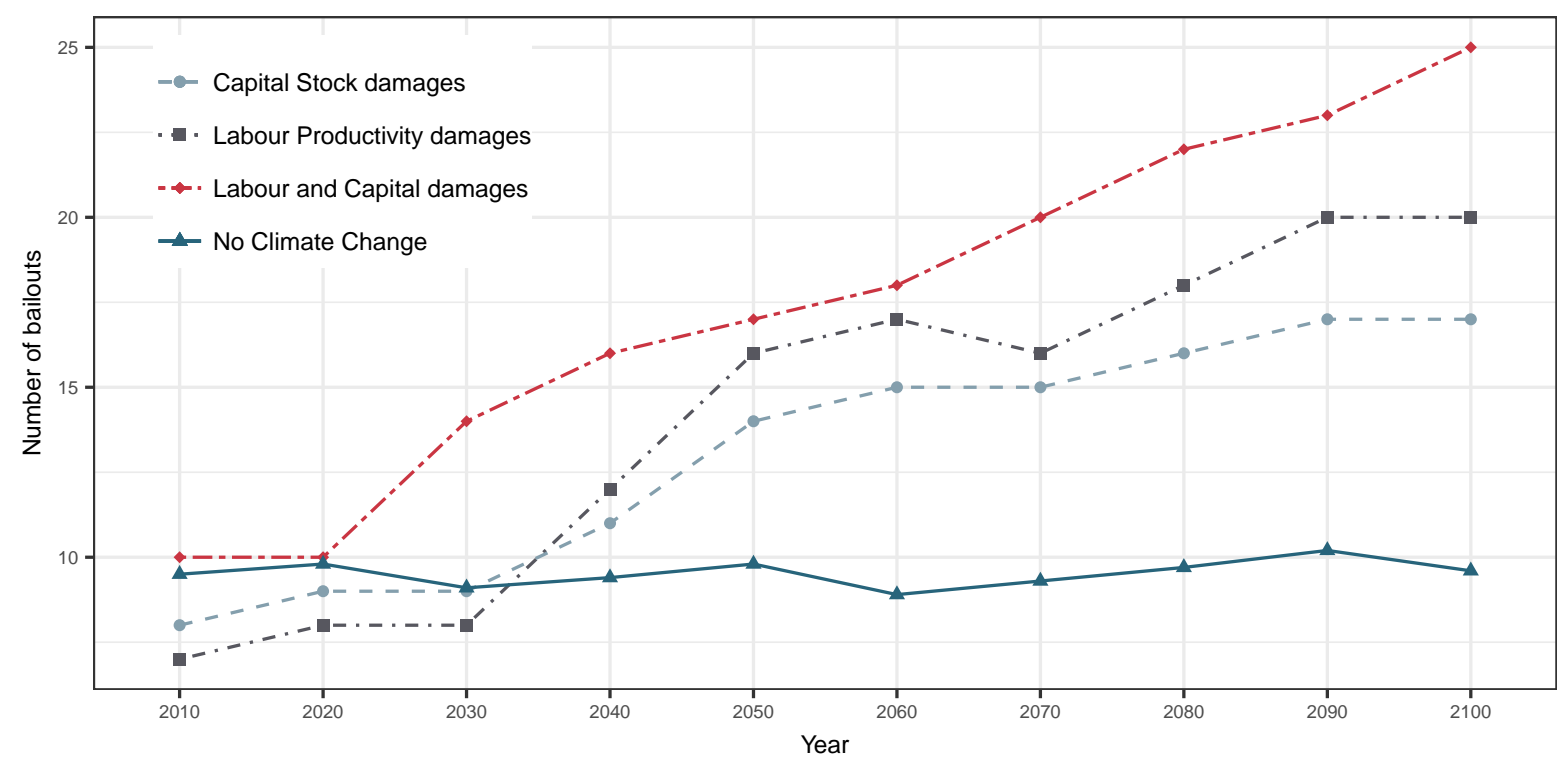

b Public costs of bailouts

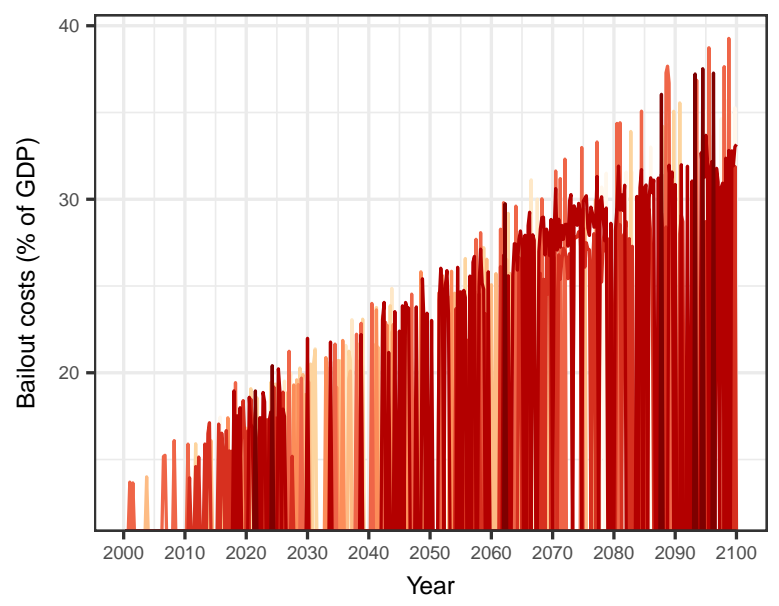

C Public debt to GDP ratio

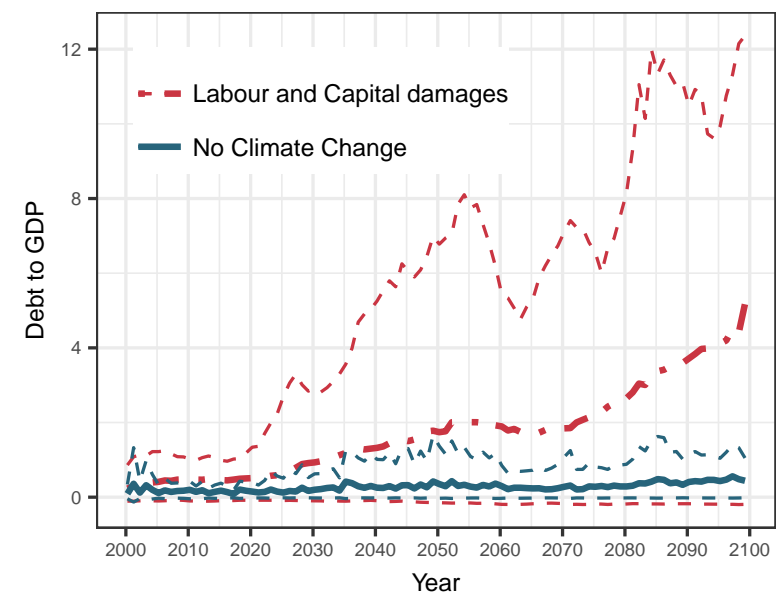

Figure 1: Climate-induced effects on the banking sector and public finances across scenarios. a, Ten-years average number of bailouts (out of 500 simulations) in the three scenarios and in the baseline. b, Bailout costs as share of GDP in the Labour and Capital Damages scenario, each line represents a model run. c, Public debt behaviour in the Labour and Capital Damages scenario and in the No Climate Change scenario, solid lines are yearly averages (out of 500 simulations) and dashed lines are $90 \%$ confidence intervals.

is run on our preferred impact scenario (Labour and Capital Damages), with results reported in Figure 2, panel c. We estimate that around 20\% (95\% CI: 5\%; 43\%) of growth rates reduction observed in the panel b of Figure 2 is attributable to financial distress (an effect of $14 \%$ is found for SSP1; see Supplementary Results, Section A).

We find that public costs of climate-induced bailouts increase approximately linearly with temperature anomaly (Figure 3). In the scenario with both labour and capital damages (panel b), such burden for the public budget moves from a yearly estimate of $17.5 \%$ (95\% CI: 8\%; $24 \%$ ) of GDP under +2.5 Celsius degrees in year 2100 to 31.0\% (95\% CI: 19\%; 48\%) for a temperature of approximately 5 Celsius degrees in the same year. These values correspond to increments of 7.14 and 20.64 percentage points with respect to the bailout costs in the baseline scenario 
a No Climate Change

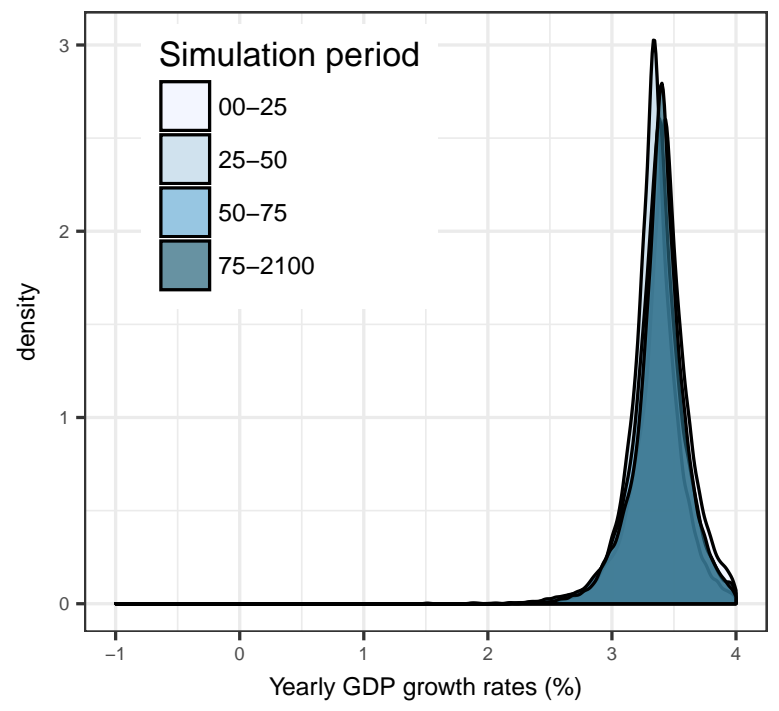

b Labour and Capital damages

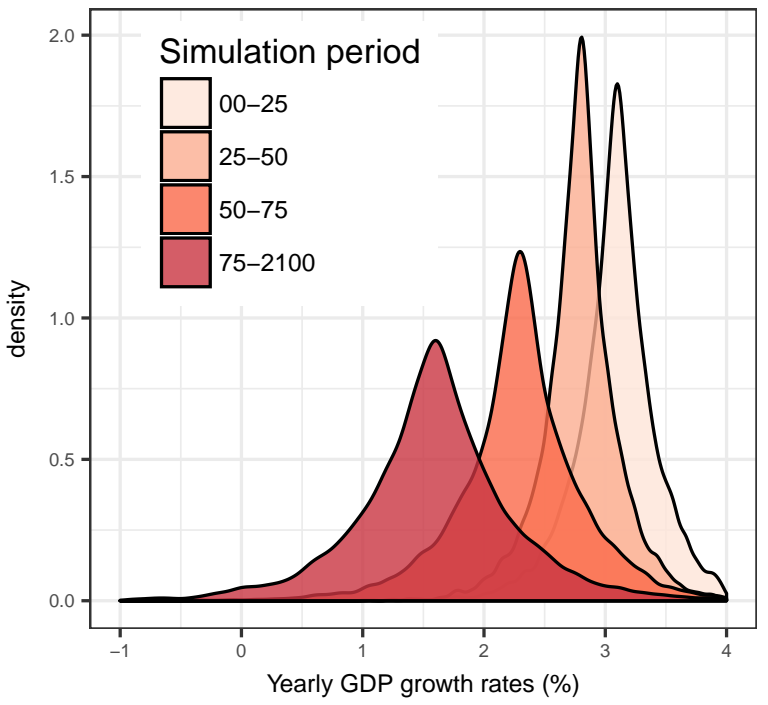

C Output growth and financial distress (Labour and Capital damages)

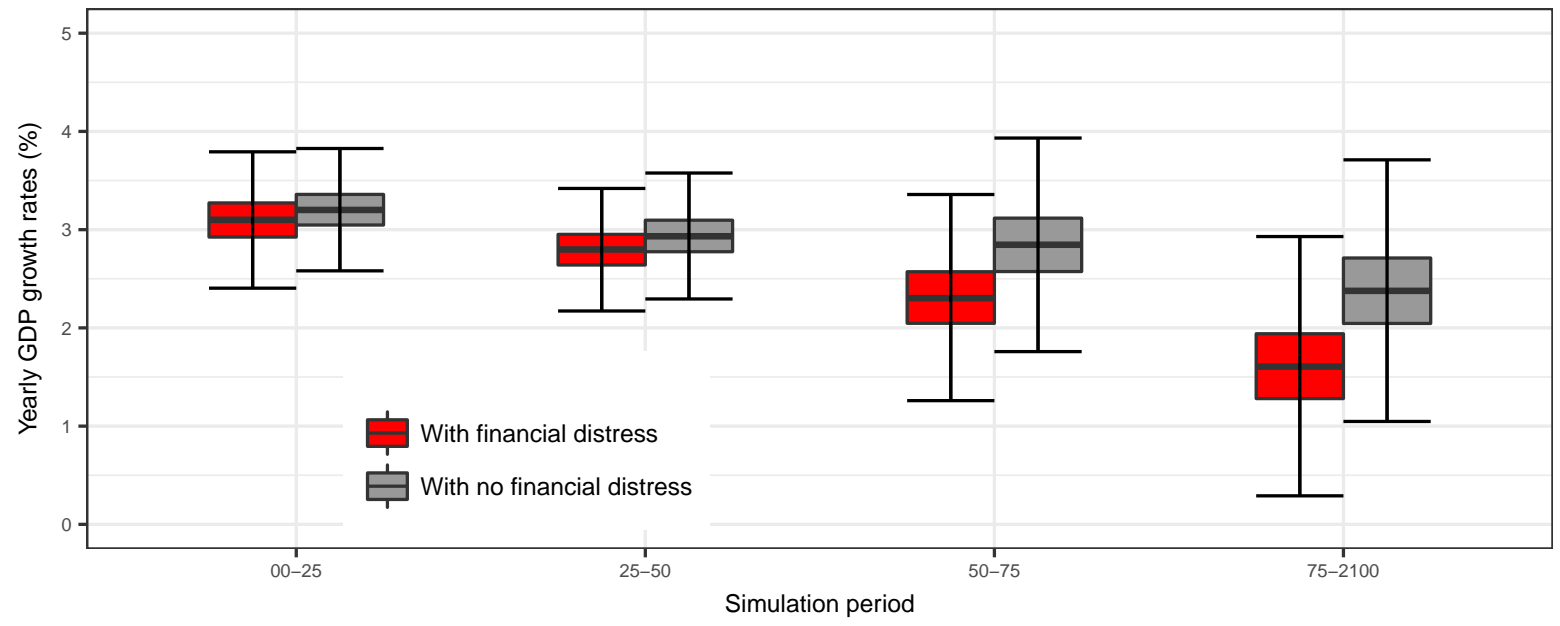

Figure 2: Global GDP growth and climate-induced instability. a,b, Kernel densities of yearly growth rates of global GDP pooled per 25-years periods in the baseline scenario with No Climate Change (a) and in the scenario with Labour and Capital Damages (b). c, Box-plots of yearly growth rates in the Labour and Capital Damages scenario in presence and absence of financial distress. Yearly growth rates are computed for each model run, clustered according to each 25-years period; a Gaussian kernel density plot is than provided for each cluster. The box-plots' whiskers contain $95 \%$ of the observations.

without climate change.

Finally, we test whether macro-prudential regulation relying on Basel-type capital requirements can help mitigate the costs of banking bailout. A U-shaped relationship emerges between banks' allowance to loan and the costs from financial distress. Tight capital requirements reduce the availability of loans, forcing firms to rely more on their highly volatile net profits. In addition, large credit supply allows firms to over-finance unsuccessful investments (21), eventually leading to losses and bankruptcies. Climate change exacerbates this relationship, with the U becoming steeper as the temperature rises. These results underscore a pivotal role of macro-prudential regulation in climate risk management. As Figure 3 (panel 
b) shows, climate-dependent capital requirements can counterbalance eventual excessive or reluctant credit provision, accounting for the impacts of climate damages on firms' solvency (12; 13). A countercyclical capital buffer (as proposed in the Basel III framework; 9) could help address climate physical risks, even though it proves ineffective when damages surge (see Supplementary Results, Section A). Nonetheless, even if such macro-prudential regulation is in place, the impact of climate change on financial crises remains dominant. This calls for a broader climate-finance policy mix fostering investments towards low carbon projects.

Supplementary Results provide a series of robustness tests. This battery of exercises confirms (i) the role of the banking system in amplifying damages; (ii) the relevance of setting adequate capital requirements, following both phases of the business cycle; and (iii) the inadequacy of contractionary fiscal policy in restoring financial stability.

a No Climate Change

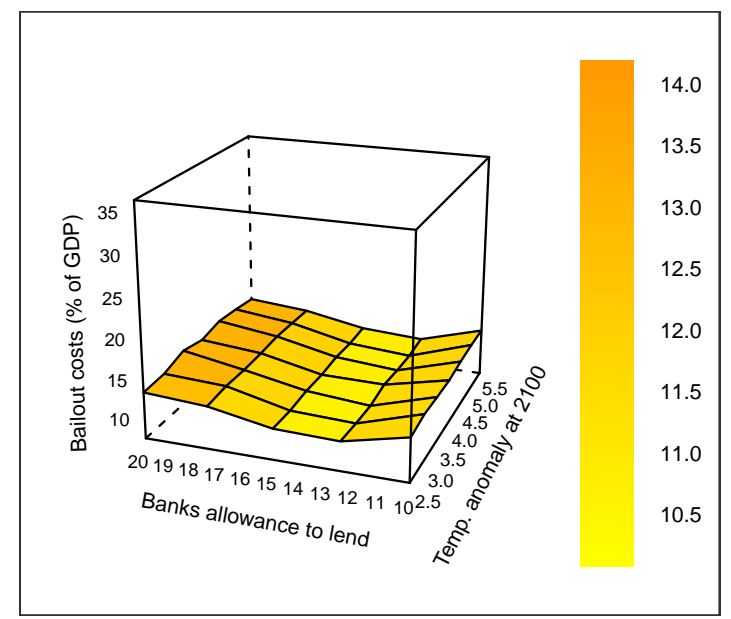

b Labour and Capital damages

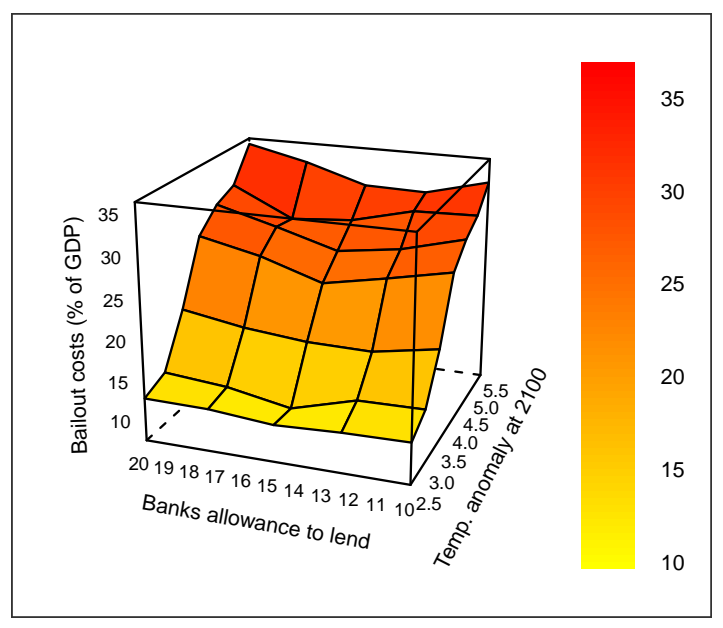

Figure 3: Public costs of climate-induced banks' bailouts. a,b Public costs of bank bailouts in the baseline scenario with absence of climate change damages (a) and in the scenario with both labour and capital damages (b). We started from the baseline configuration and let the parameter $\tau_{C A R}$ vary (see Methods) to obtain a multiplier $1 / \tau_{C A R}$ (i.e. banks' allowance to lend) as indicated in the Figure. Then, we sample 100 times the parameters controlling the growth rate of the economy within a $\pm 10 \%$ range with respect to the baseline (see Supplementary Methods, Section D). For each combination we perform a Monte Carlo exercise of 100 runs. Points in the graphs show the average yearly cost of bailout in the cluster of runs whose 2100 temperature anomaly falls in the represented interval.

The public costs of climate-induced banking instability are significant, corresponding to a yearly average of $30 \%$ of GDP in an SSP $5+$ RCP 8.5 future (against $10.3 \%$ in the scenario with no climate change). Such a result should be tentatively compared with a historical average, which was doubtfully affected by climate change, of 3.5 financial crises per year at the global level, producing fiscal costs averaging $12 \%$ of the GDP of the affected country (29). Although it is admittedly difficult to match model results with reality, the systematic comparison of our impact scenarios with the baseline configuration robustly shows that climate damages affecting the micro-economic behaviour of firms and workers cause a significant amount of additional non-performing loans, threatening solvency of financial institutions. This situation requires an extraordinary support from the government to absorb losses.

While our results might overestimate bailout costs because of a baseline with relatively 
many crises, they also completely neglect (i) any secondary systemic effects of banks' equity deterioration, such that financial institutions exposed to troubled banks may suffer losses in the market value of their assets, potentially triggering contagion phenomena (27, 41; 16); and (ii) firms' equity holding by banks. Another reason for the potential underestimation comes from the missing link between the energy industry and the banking system.

Our results suggest a central role for macro-prudential policies in managing climateinduced financial risks, which might be integrated in a more comprehensive set of adaptation and mitigation interventions. The emerging evidence of a U-shaped relationship between costs of restructuring in the banking sector and its lending propensity evidences the existence of an optimal level of capital adequacy requirements, balancing the needs of fueling investments and increasing resilience. The findings indicate that deviations from such policy exacerbate bailout costs as temperatures rise. In addition, we report evidence that climate damages reverberate to the financial system, inducing feedback loops that sharpen macroeconomic damages vis-à-vis a system in which allocation of capital is assumed to be frictionless. Thus, we suggest that integrated assessment models of climate change (48) should begin including a financial system and financial regulation authorities. Both direct and indirect effects (i.e. linked to contagion phenomena) on the financial system need to be considered, as well as regulations mitigating this potential vicious cycle.

\section{References}

[1] A. Adhvaryu, N. Kala, and A. Nyshadham. The light and the heat: Productivity cobenefits of energy-saving technology. Technical report, National Bureau of Economic Research, 2018.

[2] M. Auffhammer. Quantifying economic damages from climate change. Fournal of Economic Perspectives, 32(4):33-52, November 2018. doi: 10.1257/jep.32.4.33. URL http: //www . aeaweb.org/articles? id=10.1257/jep.32.4.33

[3] T. Balint, F. Lamperti, A. Mandel, M. Napoletano, A. Roventini, and A. Sapio. Complexity and the economics of climate change: a survey and a look forward. Ecological Economics, 138:252-265, 2017.

[4] R. Bansal, D. Kiku, and M. Ochoa. Price of long-run temperature shifts in capital markets. Technical report, National Bureau of Economic Research, 2016.

[5] S. Batten et al. Climate change and the macro-economy: a critical review. Technical report, Bank of England, 2018.

[6] S. Battiston, G. Caldarelli, M. DfiErrico, and S. Gurciullo. Leveraging the network: a stress-test framework based on debtrank. Statistics \& Risk Modeling, 33(3-4):117-138, 2016.

[7] S. Battiston, A. Mandel, I. Monasterolo, F. Schütze, and G. Visentin. A climate stresstest of the financial system. Nature Climate Change, 7:283 EP -, 03 2017. URL http : //dx.doi.org/10.1038/nclimate3255.

[8] B. S. Bernanke, C. S. Lown, and B. M. Friedman. The credit crunch. Brookings Papers on Economic Activity, 1991(2):205-247, 1991. ISSN 00072303, 15334465. URL http: //www.jstor.org/stable/2534592. 
[9] BIS. Basel iii: A global regulatory framework for more resilient banks and banking systems. Technical report, Basel Committee on Banking Supervision, 2011.

[10] M. K. Brunnermeier. Deciphering the liquidity and credit crunch 2007-2008. Fournal of Economic Perspectives, 23(1):77-100, March 2009. doi: 10.1257/jep.23.1.77. URL http : //www . aeaweb.org/articles?id=10.1257/jep.23.1.77

[11] M. Burke, S. M. Hsiang, and E. Miguel. Global non-linear effect of temperature on economic production. Nature, 527(7577):235, 2015.

[12] E. Campiglio. Beyond carbon pricing: The role of banking and monetary policy in financing the transition to a low-carbon economy. Ecological Economics, 121: 220 - 230, 2016. ISSN 0921-8009. doi: http://dx.doi.org/10.1016/j.ecolecon.2015.03. 020. URL http://wWW. sciencedirect.com/science/article/pii/ S0921800915001056.

[13] E. Campiglio, Y. Dafermos, P. Monnin, J. Ryan-Collins, G. Schotten, and M. Tanaka. Climate change challenges for central banks and financial regulators. Nature Climate Change, 8(6):462, 2018.

[14] T. A. Carleton and S. M. Hsiang. Social and economic impacts of climate. Science, 353 (6304):aad9837, 2016.

[15] M. Carney. Breaking the tragedy of the horizon: climate change and financial stability. Speech given at Lloydfis of London, 2015.

[16] M. Chinazzi and G. Fagiolo. Systemic risk, contagion, and financial networks: A survey. In I. A. Fernández and E. Tortosa, editors, Banking Integration and Financial Crisis: Some Recent Developments. Fundacion BBVA, 2015.

[17] Y. Dafermos, M. Nikolaidi, and G. Galanis. Climate change, financial stability and monetary policy. Ecological Economics, 152:219 - 234, 2018. ISSN 0921-8009. doi: https: //doi.org/10.1016/j.ecolecon.2018.05.011. URL http://wWW.sciencedirect. com/science/article/pii/s0921800917315161.

[18] M. Dell, B. F. Jones, and B. A. Olken. Temperature and income: Reconciling new cross-sectional and panel estimates. American Economic Review, 99(2):198-204, May 2009. doi: 10.1257/aer.99.2.198. URL http://www . aeaweb.org/articles? id $=10.1257 /$ aer.99.2.198

[19] S. Dietz, A. Bowen, C. Dixon, and P. Gradwell. ficlimate value at riskfiof global financial assets. Nature Climate Change, 6(7):676, 2016.

[20] N. S. Diffenbaugh and M. Burke. Global warming has increased global economic inequality. Proceedings of the National Academy of Sciences, 116(20):9808-9813, 2019. ISSN 00278424. doi: 10.1073/pnas.1816020116. URL https : / / www . pnas . org/content/ $116 / 20 / 9808$

[21] G. Dosi, G. Fagiolo, M. Napoletano, and A. Roventini. Income distribution, credit and fiscal policies in an agent-based Keynesian model. Fournal of Economic Dynamics and Control, 37(8):1598 - 1625, 2013. ISSN 0165-1889. doi: http://dx.doi.org/10.1016/j.jedc.2012.11. 008. URL http : //wWw. sciencedirect.com/science/article/pii/ 
S0165188913000213. Rethinking Economic Policies in a Landscape of Heterogeneous Agents.

[22] G. Fagiolo and A. Roventini. Macroeconomic policy in DSGE and agent-based models redux: New developments and challenges ahead. Journal of Artificial Societies and Social Simulation, 20(1), 2017.

[23] HLEG. Financing a sustainable european economy. Technical report, European Commission, 2017. High Level Expert Group on Sustainable Finance - interim report.

[24] S. Hsiang, R. Kopp, A. Jina, J. Rising, M. Delgado, S. Mohan, D. J. Rasmussen, R. MuirWood, P. Wilson, M. Oppenheimer, K. Larsen, and T. Houser. Estimating economic damage from climate change in the united states. Science, 356(6345):1362-1369, 2017. ISSN 0036-8075. doi: 10.1126/science.aal4369. URL http://science.sciencemag . org/content/356/6345/1362

[25] S. M. Hsiang. Temperatures and cyclones strongly associated with economic production in the caribbean and central america. Proceedings of the National Academy of sciences, page 201009510, 2010.

[26] Ò. Jordà, M. Schularick, and A. M. Taylor. When credit bites back. Journal of Money, Credit and Banking, 45(s2):3-28, 2013.

[27] N. Kiyotaki and J. Moore. Balance-sheet contagion. American Economic Review, 92(2): 46-50, 2002.

[28] T. Kjellstrom, R. S. Kovats, S. J. Lloyd, T. Holt, and R. S. Tol. The direct impact of climate change on regional labor productivity. Archives of Environmental \& Occupational Health, 64(4):217-227, 2009.

[29] L. Laeven and F. Valencia. Systemic banking crises database: An update. data sets., 2012. URL https://WwW.imf.org/en/Publications/WP/Issues/2016/ 12/31/Systemic-Banking-Crises-Database-An-Update-26015

[30] F. Lamperti, G. Dosi, M. Napoletano, A. Roventini, and A. Sapio. Faraway, so close: Coupled climate and economic dynamics in an agent-based integrated assessment model. Ecological Economics, 150:315 - 339, 2018. ISSN 0921-8009. doi: https://doi.org/10.1016/ j.ecolecon.2018.03.023. URL http : //WWW. sciencedirect . com/science/ article/pii/S0921800917314623.

[31] F. Lamperti, G. Dosi, M. Napoletano, A. Roventini, and A. Sapio. And then he wasnfit a she: Climate change and green transitions in an agent-based integrated assessment model. LEM working paper series, Scuola Superiore Sant'Anna, Institute of Economics, 2018.

[32] J. Martinich and A. Crimmins. Climate damages and adaptation potential across diverse sectors of the united states. Nature Climate Change, 9(5):397-404, 2019. doi: 10.1038/s41558-019-0444-6. URL https://doi.org/10.1038/ S41558-019-0444-6.

[33] J.-F. Mercure, H. Pollitt, J. E. Viñuales, N. R. Edwards, P. B. Holden, U. Chewpreecha, P. Salas, I. Sognnaes, A. Lam, and F. Knobloch. Macroeconomic impact of stranded fossil fuel assets. Nature Climate Change, 8(7):588, 2018. 
[34] W. Nordhaus. Estimates of the social cost of carbon: Concepts and results from the DICE2013R model and alternative approaches. Fournal of the Association of Environmental and Resource Economists, 1(1/2):273-312, 2014. URL http://WWW.jstor.org/ stable/10.1086/676035.

[35] W. D. Nordhaus. Revisiting the social cost of carbon. Proceedings of the National Academy of Sciences, page 201609244, 2017.

[36] OECD. OECD Employment Outlook 2018. OECD Publishing, Paris, 2018.

[37] C. M. Reinhart and K. S. Rogoff. The aftermath of financial crises. American Economic Review, 99(2):466-72, 2009.

[38] C. M. Reinhart and K. S. Rogoff. This time is different: Eight centuries of financial folly. princeton university press, 2009.

[39] K. Riahi, D. P. van Vuuren, E. Kriegler, J. Edmonds, B. C. OfiNeill, S. Fujimori, N. Bauer, K. Calvin, R. Dellink, O. Fricko, W. Lutz, A. Popp, J. C. Cuaresma, S. KC, M. Leimbach, L. Jiang, T. Kram, S. Rao, J. Emmerling, K. Ebi, T. Hasegawa, P. Havlik, F. Humpender, L. A. D. Silva, S. Smith, E. Stehfest, V. Bosetti, J. Eom, D. Gernaat, T. Masui, J. Rogelj, J. Strefler, L. Drouet, V. Krey, G. Luderer, M. Harmsen, K. Takahashi, L. Baumstark, J. C. Doelman, M. Kainuma, Z. Klimont, G. Marangoni, H. Lotze-Campen, M. Obersteiner, A. Tabeau, and M. Tavoni. The shared socioeconomic pathways and their energy, land use, and greenhouse gas emissions implications: An overview. Global Environmental Change, 42:153 - 168, 2017. ISSN 0959-3780. doi: https://doi.org/10.1016/j. gloenvcha.2016.05.009. URL http://www. sciencedirect.com/science/ article/pii/s0959378016300681.

[40] K. Ricke, L. Drouet, K. Caldeira, and M. Tavoni. Country-level social cost of carbon. Nature Climate Change, 2018. doi: 10.1038/s41558-018-0282-y. URL https : / / doi . org/10.1038/s41558-018-0282-y.

[41] T. Roukny, H. Bersini, H. Pirotte, G. Caldarelli, and S. Battiston. Default cascades in complex networks: Topology and systemic risk. Scientific reports, 3:2759, 2013.

[42] K. Safarzyńska and J. C. van den Bergh. Financial stability at risk due to investing rapidly in renewable energy. Energy Policy, 108:12-20, 2017.

[43] W. Schlenker and M. J. Roberts. Nonlinear temperature effects indicate severe damages to us crop yields under climate change. Proceedings of the National Academy of sciences, 106(37):15594-15598, 2009.

[44] O. Seppanen, W. J. Fisk, and D. Faulkner. Cost benefit analysis of the night-time ventilative cooling in office building. Technical report, Lawrence Berkeley National Laboratory, 2003.

[45] O. Seppanen, W. J. Fisk, and Q. Lei. Effect of temperature on task performance in office environment. Technical report, Lawrence Berkeley National Laboratory, 2006.

[46] E. Somanathan, R. Somanathan, A. Sudarsan, and M. Tewari. The impact of temperature on productivity and labor supply: Evidence from indian manufacturing, 2014. URL https://EconPapers.repec.org/RePEc:ess : wpaper:id: 6308 . 
[47] A. Trinks, B. Scholtens, M. Mulder, and L. Dam. Fossil fuel divestment and portfolio performance. Ecological Economics, 146:740-748, 2018.

[48] J. Weyant. Some contributions of integrated assessment models of global climate change. Review of Environmental Economics and Policy, 11(1):115-137, 2017.

\section{Corresponding author}

All requests for additional information and simulation data can be made to Francesco Lamperti, emails: francesco.lamperti[at]eiee.org or f.lamperti[at]santannapisa.it.

\section{Acknowledgements}

The authors gratefully acknowledge support from Fondazione Eni Enrico Mattei, FEEM. The research leading to these results received funding from the European Research Council under the European Communityfis Programme "Ideas" - Call identifier: ERC-2013-StG / ERC grant agreement n. 336703 project RISICO "RISk and uncertainty in developing and Implementing Climate change pOlicies" and from the European Research Council under the European Unionfis Seventh Framework Programme (FP7/2007-2013) / ERC grant agreement n. 336155 - project COBHAM "The role of consumer behaviour and heterogeneity in the integrated assessment of energy and climate policies". This paper is also part of a project that has received funding from the European Union H2020 Research and Innovation programme under the Marie Skffodowska-Curie grant agreement n. 681228 - GEMCLIME and from the European Union H2020 Research and Innovation action under grant agreement n. 822781 - GROWINPRO. A special thank to Tania Treibich and Mattia Guerini for helpful discussions, comments and support. We also thank participants at ECOMOD 2018 (Venice), EAEPE 2018 (Nice), to the 2018 Workshop on Economic and Financial Implications of Climatic Change (Milan), WEHIA 2019 and to the seminars at IAASA and Universitè Paris Panthèon-Sorbonne.

\section{Authors' contributions}

All authors contributed equally to the project planning, design of the simulation experiments, to the analysis of the results and to the writing of the paper. FL also developed the code and ran the simulations.

\section{Competing interests}

The authors declare no competing interests.

\section{Methods}

This paper makes use of a novel development of the Dystopian Schumpeter meeting Keynes (DSK) model (30) to evaluate the impacts of climate change on the financial system, intended as a stylized but realistic banking sector. The DSK model is an agent-based simulation laboratory representing a global economy and its relationship to changes in mean surface temperature. In particular, the model comprises heterogeneous and interacting firms, devoted to the production of either capital or consumption goods and receiving inputs from an energy sector, a financial system and a variety of households. Firms compete to serve both the demand of capital and consumption goods; in the case of failure, a novel 
firm with average characteristics of the firm pool enters the relevant market. Anthropogenic emissions arise from production of goods and, especially, energy, while there is no formal representation of land use and transportation. Cumulative emission are linked to temperature increases through a single equation model calibrated on recent estimates of the carbon-climate response (60). Economic growth is driven by endogenous technical change, which ameliorates the set of technologies available to both firms and energy plants. The major modelling innovation this paper brings about is the inclusion of a financial system of multiple heterogeneous banks. The role of the banking sector has historically proved to be pivotal in modern economies, with both positive and negative effects. Primarily, banks collect deposits from households and provide credit to firms to fuel their investments and, thus, spurring economic growth. By contrast, when banks experience financial troubles incurring in equity losses, they freeze funding opportunities for the real economy and slow down productivity growth. In our model, we account for both these features through imperfect capital markets. The banking sector, based on (55), encompasses $B$ commercial banks that gather deposits from households/workers and provide credit to firms, plus a single central bank running monetary policy and buying government bonds when necessary. Banks are heterogeneous in their number of clients, balance-sheet structure and lending conditions. Imperfect information prevents firms from screening all existing banks in search for optimal lending rates; the bank-firm network is assumed to be fixed and it reflects the empirical distribution of bank size. The crucial decision for a financial institution concerns the amount of credit to provide to clients. We assume that the supply of credit is a multiple of a bank's net worth (i.e. equity):

$$
T C_{b}(t)=\frac{N W_{b}(t-1)}{\tau_{C A R}\left(1+\frac{\beta B D_{b}(t-1)}{T A_{b}(t-1)}\right)},
$$

where $T C$ is the total credit supplied by bank $b$ at time $t, N W$ denotes the value of the bank's equity and $T A$ is the value of total assets. Credit supply is thus affected by changes in the banks' balance sheet, which is itself affected by bank profits net of loan losses. Furthermore, the policy parameter $\tau_{C A R}$ indicates capital adequacy requirements, while $\beta$ is a behavioural parameter measuring banks' sensitivity to financial fragility of their balance sheet. These two parameters contribute to determining the lending ability of a bank to the real economy: on one side, capital adequacy requirements inspired by Basel-framework rules constrain banks' credit supply; on the other side, evidence indicates that banks maintain a buffer over the mandatory level of capital, whose magnitude is strategically altered over the business cycle according to their financial fragility $(53,52)$, which is proxied by the ratio of "bad debt" ( $B D$, indicating the amount of non-performing loans) to total assets of bank $b$. Indeed, the larger the stock of bad debt created by insolvent firms in a given period, the higher its financial fragility and the lower the amount of credit a bank will supply to the economy. This is the major link among climate change impacts, banking crises and macro-economic dynamics: if climate damages lead firms to bankruptcy, the loss transmits to the financial system, in which banks exposed to defaulted firms suffer reductions in their equity value. Such an effect provides feedback to the real economy in terms of lower credit supply, and if large enough, it might also threaten the very solvency of banks. The fact that the amount of capital lent to firms shrinks during downturns and financial crises, eventually leading to credit crunches, is a well established empirical regularity, and the recent financial crisis was not an exception (51; 58, 57). However, we remark other channels leading to financial instability might exist (13). In our set-up, banks do not exchange assets (e.g. overnight loans), and therefore, contagion effects due to interbank exposure are absent, potentially leading to an underestimation of the true societal costs of climate impacts to the financial sector. Crucially, to estimate the public cost of banks' instability, we assume the government bails out insolvent banks, which re-capitalizes their equity in the period ahead, preventing the default. In particular, the government is providing fresh capital amounting to a fraction of the smallest incumbent equity, provided that it satisfies the Baseltype capital adequacy requirements (banks' equity to total loans ratio larger than a given threshold, which equals $8 \%$ in our simulations). In such a context, heterogeneity is crucial, as banks with diverse capital structures are differentially vulnerable to (climate-induced) shocks and differentially affect the 
macro-economy in case of failure (57), while also possibly triggering bankruptcy cascades. In this respect, our modelling choice allows for a genuine and realistic representation of heterogeneity and interactions among ecologies of individuals. Agent-based models have been increasingly advocated as adequate tools to study complex and intricate set of relationships, especially in climate-change economics (61; 66; 3), macroeconomics (22) and finance (54; 56), where top-down aggregate modelling might hide effects that bottom-up approaches allow disentangling. The model is validated through stylized fact replication at both the micro-economic level (e.g. firm size distribution, heterogeneity in productivity, lumpy investment behaviour) and the macro-economic level (e.g. persistent fluctuations in output, identification of cyclical, leading and lagging indicators, distribution of banking crises). A detailed description of the stylized facts replicated by the model is contained in Supplementary Methods, Section C while the description of the model itself is available in Supplementary Methods, Section B.

The model does not allow for analytical, closed-form solutions. This stems from the non-linearities that characterize agents' decision rules and their interaction patterns and forces us to run computer simulations to analyze the properties of the stochastic processes governing the co-evolution of microand macro-variables. Fagiolo and Roventini (22) and Balint et al. (3) provide an overview of agent based macroeconomic models and their technical details. In what follows, we therefore perform Monte Carlo analyses to remove across-simulation variability and present results as averages over 500 model runs, as standard in the literature.

The DSK model is calibrated on a coupled SSP 5-RCP 8.5 scenario (67) characterized by high growth (63), sustained energy demand (39) and soaring emission concentrations until the end of the century (65). The choice of such a scenario is justified by two reasons. First, we wanted to isolate the effects of climate-induced financial instability in a context of strong climate change and substantial damages, in a way to evaluate the aggregate effects of mechanisms (default chains) that might be opaque under milder conditions. Second, we deliberately target a worst-case scenario with the aim to characterize the financial costs of inaction, thus providing a first estimate of the public costs of banking fragility associated with climate change under business as usual. The economy-climate linkage is voluntarily simple and makes use of the well-documented approximately linear relationship translating cumulative emissions in temperature increases (59, 50), with the preferred specification assuming global mean surface temperature to rise by 1.8 Celsius degrees for each emitted $1000 \mathrm{GtC}(\overline{60})$. We model economic losses due from temperature changes at the level of firms, which might suffer damages to either their labour or capital production factors (19), while the average climate-induced shock follows the quadratic damage function employed in the DICE 2016R model (35):

$$
\Omega(t)=\frac{1}{1+c_{1} T(t)+c_{2} T(t)^{2}},
$$

where $T$ indicates the mean surface temperature anomaly and $c_{1}=0, c_{2}=0.0022$. Such a configuration implies a $0.236 \%$ loss per degree Celsius squared; this leads to a damage of $2.1 \%$ at $+3{ }^{\circ} \mathrm{C}$, and $8.5 \%$ at a global temperature rise of $6{ }^{\circ} \mathrm{C}$. To put these numbers into perspective, during the Great Recession (2007-2013), most developed countries experienced average losses in output of $2.66 \%$ per year, a loss of capital intensity of $0.40 \%$ per year and a loss in productivity of $1.30 \%$ per year (64). Using an oversimplification, for the average firm, imposing a $2 \%$ damage in a given period is vaguely similar to experiencing one year of the recent crisis. The relevant difference with respect to the standard use of such damage functions (e.g. 62, 34) and from (35) in particular, is that we do not assume that $\Omega(t)$ affect the global output (i.e. GDP). Rather, employing a model with multiple agents instead of an aggregate economic sector, we consider microeconomic damages, $D_{i}(t)=\Omega(t)+\epsilon_{i}$ with $\epsilon_{i} \approx$ i.i.d. $\mathrm{N}(0,0.01)$, hitting each firm. That is, in a scenario where climate change only affects capital stocks (e.g. 19), each firm receives a loss of capital amounting to $0.236 \%$ on average for each ${ }^{\circ} \mathrm{C}$ of temperature increase. The term $\epsilon_{i}$ captures the fact that different firms (e.g. at different locations) tend to suffer a different damage (24, 40).

Then, we design three impact scenarios: (i) climate damages target the productivity of labour, (ii) 
climate damages target the availability of physical capital and (iii) climate damages target both labour productivity and capital stock, with the relative impact weighted according to global labour and capital shares of GDP (19). By contrast, the baseline configuration of the model runs in absence of climate change and, thus, climate damages. The only difference between the baseline and the three impact scenarios is the presence of climate change (see Supplementary Methods, Section C). In addition, to isolate the effect of climate-induced financial distress on the real economy we run a counter-factual numerical experiment (Figure 2 panel c) in which we assume that the government exchanges the nonperforming loans due to firms' bankruptcies with liquidity to impede deterioration of banks' net worth (equities). In particular, in the experiment without financial distress, the government provides liquidity for an amount equivalent to the non-performing loan.

\section{Data availability}

The simulation data that support the findings of this study are available from the corresponding author upon request.

\section{Code availability}

The code that support the findings of this study are available from the corresponding author upon request.

\section{References}

[50] M. R. Allen, D. J. Frame, C. Huntingford, C. D. Jones, J. A. Lowe, M. Meinshausen, and N. Meinshausen. Warming caused by cumulative carbon emissions towards the trillionth tonne. Nature, 458(7242):1163, 2009.

[51] B. S. Bernanke. Nonmonetary effects of the financial crisis in the propagation of the great depression. The American Economic Review, 73(3):257-276, 1983. ISSN 00028282. URL http: //www.jstor.org/stable/1808111.

[52] J. Bikker and P. Metzemakers. Bank provisioning behaviour and procyclicality. Fournal of International Financial Markets, Institutions and Money, 15(2):141 - 157, 2005. ISSN 1042-4431. doi: https://doi.org/10.1016/j.intfin.2004.03.004. URL http://WWW.sciencedirect.com/ science/article/pii/S1042443104000678

[53] BIS. Capital requirements and bank behaviour: the impact of the basle accord. Technical Report 1, Bank for International Settlements Basel, 1999.

[54] E. Bonabeau. Agent-based modeling: Methods and techniques for simulating human systems. Proceedings of the National Academy of Sciences, 99(suppl 3):7280-7287, 2002.

[55] G. Dosi, G. Fagiolo, M. Napoletano, A. Roventini, and T. Treibich. Fiscal and monetary policies in complex evolving economies. Fournal of Economic Dynamics and Control, 52:166 - 189, 2015. ISSN 0165-1889. doi: http://dx.doi.org/10.1016/j.jedc.2014.11.014. URL http://wWw. sciencedirect.com/science/article/pii/s016518891400311X

[56] J. D. Farmer and D. Foley. The economy needs agent-based modelling. Nature, 460(7256):685, 2009. 
[57] G. Jimnez, S. Ongena, J.-L. Peydr, and J. Saurina. Macroprudential policy, countercyclical bank capital buffers, and credit supply: Evidence from the spanish dynamic provisioning experiments. Fournal of Political Economy, 125(6):2126-2177, 2017. doi: 10.1086/694289. URL https : //doi. org/10.1086/694289.

[58] C. Lown and D. P. Morgan. The credit cycle and the business cycle: new findings using the loan officer opinion survey. Journal of Money, Credit and Banking, pages 1575-1597, 2006.

[59] H. D. Matthews, N. P. Gillett, P. A. Stott, and K. Zickfeld. The proportionality of global warming to cumulative carbon emissions. Nature, 459(7248):829, 2009.

[60] H. D. Matthews, S. Solomon, and R. Pierrehumbert. Cumulative carbon as a policy framework for achieving climate stabilization. Phil. Trans. R. Soc. A, 370(1974):4365-4379, 2012.

[61] J.-F. Mercure, H. Pollitt, A. M. Bassi, J. E. Viñuales, and N. R. Edwards. Modelling complex systems of heterogeneous agents to better design sustainability transitions policy. Global Environmental Change, 37:102 - 115, 2016. ISSN 0959-3780. doi: http://dx.doi.org/10.1016/j.gloenvcha. 2016.02.003. URL http://WWW. sciencedirect.com/science/article/pii/ S0959378016300139

[62] W. D. Nordhaus. An optimal transition path for controlling greenhouse gases. Science, 258(5086): 1315-1319, 1992. doi: 10.1126/science.258.5086.1315. URL http://wWw. sciencemag. org/content/258/5086/1315.abstract

[63] B. C. O’Neill, E. Kriegler, K. Riahi, K. L. Ebi, S. Hallegatte, T. R. Carter, R. Mathur, and D. P. van Vuuren. A new scenario framework for climate change research: the concept of shared socioeconomic pathways. Climatic Change, 122(3):387-400, Feb 2014. ISSN 1573-1480. doi: 10. 1007/s10584-013-0905-2. URL https : //doi .org/10 .1007/s10584-013-0905-2

[64] N. Oulton. Productivity and the great recession. Intereconomics, 53:63-68, 2018.

[65] K. Riahi, S. Rao, V. Krey, C. Cho, V. Chirkov, G. Fischer, G. Kindermann, N. Nakicenovic, and P. Rafaj. Rcp 8.5fi!?a scenario of comparatively high greenhouse gas emissions. Climatic Change, 109(1-2):33, 2011.

[66] N. Stern. Current climate models are grossly misleading. Nature, 530(7591):407-409, 2016.

[67] D. P. van Vuuren, E. Kriegler, B. C. O’Neill, K. L. Ebi, K. Riahi, T. R. Carter, J. Edmonds, S. Hallegatte, T. Kram, R. Mathur, and H. Winkler. A new scenario framework for climate change research: scenario matrix architecture. Climatic Change, 122(3):373-386, Feb 2014. ISSN 1573-1480. doi: 10. 1007/s10584-013-0906-1. URL https://doi .org/10 .1007/s10584-013-0906-1 